\title{
Reflexive audiovisual methodology: The emergence of "minority practices" among pluriactive stock farmers
}

\author{
Pierre Marie Stassart*, Valérie Mathieu, François Mélard \\ Liège University, Campus Arlon, Avenue Longwy 185, B-6700 Arlon, Belgium
}

\section{Keywords:}

Participatory research

Methodology

Pragmatism

Filmmaking

Stock farming

Pluriactivity

\begin{abstract}
A B S T R A C T
This paper proposes a new way for sociology, through both methodology and theory, to understand the reality of social groups and their "minority practices." It is based on an experiment that concerns a very specific category of agriculturalists called "pluriactive" stock farmers. These stock farmers, who engage in raising livestock part-time alongside another full-time job, form a minority category within the agricultural profession.

We address the question of how to analyze and represent the practices of this kind of "social" group or category through participatory filmmaking. Our research shows that beyond the collaborative production and screening of the film done in close cooperation with the stock farmers themselves, a second unexpected dynamic emerged around the sequences that were cut in the final editing round. These cut sequences reveal hesitations and disagreements among the breeders about their own practices in relation to their work and to animal welfare. These hesitations are not considered weaknesses, but rather as proof of the emergence of this group of stock farmers as "practitioners". In the realm of intervention research, the participatory film-making process is attractive because it enables the farmers to raise new questions on their own, discuss them, and eventually resolve them, while also encouraging the researchers to identify the conditions that must be met in order to achieve this fragile linkage. This process and its outcomes force us to revisit the theoretical question of what constitutes a pragmatic definition of a "practice."
\end{abstract}

(c) 2011 Elsevier Ltd. All rights reserved.
How to succeed in "working together"...where phenomena continue...to speak in many voices; where they refuse to be reinvented as univocal witnesses (Stengers, 1997)

This methodology paper asks the following question: how does one account for or describe a group's practices? We reformulate this classic problem of the social sciences by asking, instead: how does one get a group to emerge? In response, we put forward a double hypothesis. The first concerns the necessity for researchers to engage in a social form of participatory research where the intersubjectivity between researchers and "actors" enables the latter take hold of their own social reality. The second one concerns the creation of that social reality: specifically, that having researchers involved in the process makes it possible for a type of collective to emerge in which "minority practices" become visible.

We address these issues through analysis of a collaborative filmmaking project led by eight stock farmers and two committed researchers (the first two authors of this paper). The case study or,

\footnotetext{
* Corresponding author. Tel.: +32 63230 816; fax: +32 63230818.

E-mail address: p.stassart@ulg.ac.be (P.M. Stassart).
}

rather, experiment, highlights a specific group of poorly known and unrecognized farmers: namely, "pluriactive" or part-time livestock farmers. A marginal group within the agricultural realm, these farmers raise their stock as a sideline to off-farm, full-time jobs or business activities.

Our contribution to the special section "Subjecting the Objective: Participation and Agroecological Research" therefore returns to a critical issue in the operationalization of sustainable development: that of taking minority groups into account. The definition of sustainable development that revolves around the three pillars of economic, environmental, and social issues has often suffered from insufficient attention to interdependencies and a tendency to separate social, economic, and environmental analyses (Kemp et al., 2005). Such treatment makes little of the role that minorities weak, poor, and marginalized - might have in the debate about sustainability and, especially, about the relationships between its three pillars. Taking up this criticism, (Newman and Kenworthy, 1999) stress the fact that, paradoxically, while global cooperation on environmental issues is an important issue, sustainable change can occur only with community-based approaches that take local 
culture seriously. Sustainable development is thus a political issue (Hajer, 1995). Our paper contributes to this discussion by investigating how to take minority groups into account so as to operationalize sustainable development in a more democratic, less technocratic, and less elitest way.

\section{Theoretical framework}

Although it was initially inspired by the reflexive visual anthropological approach, our participatory research in fact belongs to the tradition of Participatory Action Research (PAR). Participatory Action Research is essentially emancipatory and political in nature (Chambers, 1989; Greenwood and Levin, 1998). It is a paradigm in which the researcher's role becomes one of encouraging participation and upholding ethical commitments. The originality of our research lies in its analysis of the connection between the production of visual materials and the production of research results, an approach about which the tradition of PAR says very little (Catalani and Minkler, 2010).

Reflexive visual anthropology proposes to take on the "fictional" side of documentary-making. It recognizes that communicating reality in its entirety is impossible (Ruby, 2000) (Pink, 2001). Unlike conventional ethnographic film, it uses the creation of visual material as an intermediary and medium in the relationship between the observer and the observed (Banks, 1998; Pink, 2001; Rouch, 2003): the researchers' reflexivity on the construction of their point of view (Ruby, 1980) and the observeds' reflexivity on the image that they create for themselves under the gazes of others (Rouch, 2003). Reflexive visual anthropology belongs to the tradition of feminist studies that defines intersubjectivity as an approach of "reciprocal sharing of knowledge and experience between researcher and the researched" and an understanding that the researcher unavoidably takes part in the production of knowledge (Shields and Dervin, 1993).

In Participatory Action Research (PAR) and, more specifically, participatory photography and variations such as "photovoice" (Wang, 1999; Catalani and Minkler, 2010), participants, local communities, and researchers create and use visual materials (drawings, photos, maps, etc.) to exchange their experiences and collectively build diagnoses and knowledge on a given topic (Prins, 2010).

Participatory photography is rooted in three theoretical traditions: Freire's philosophy (Freire, 1973) of using photographic materials and drawings to analyze social issues and collective action; feminist critiques and reconceptualizations of sociocultural power (Maguire, 1987); and community-based photography, in which ordinary people use "images of themselves" to counteract stereotypes (Spence, 1995 cited by Wang and Redwood-Jones, 2001). By having subjects use visual materials to document their perspectives, the participatory photography method can unearth meanings and actions that subjects would otherwise seldom - or poorly - express in words (Barndt, 2001) cited by (Prins 2010)). However, the gap between the methodological ideal and the reality of practices remains a challenge for participatory photography, for many reasons (Williams and Lykes, 2003). For one, photographs are difficult to decode as they are embedded in complex local histories and asymmetrical social relations. Further, making the invisible visible through photos creates controversy and tension within groups (Mcintyre, 2003). Finally, romanticized views on some epistemological and ethical issues can lead researchers to put too much faith in the equalizing effects of participatory research. They may naively assume that they have subverted the researcher/ participant hierarchy (Smith et al., 2010) and given voice, autonomy, and transformative results to the paricipants when, in reality, they have only silenced them in new ways.
The production of visual materials as intermediaries between researchers and participants raises the question of the audience for whom the materials are intended. The process of defining an audience often raises suble and unexpected challenges (Pini, 2001) that Esther Prins described as "ethical dilemmas" (Prins, 2010). Film is a technology of power with contradictory potential. On the one hand it can empower; it equips marginalized groups with the tools they need to bring knowledge and practices to light by challenging dominant notions of what counts as knowledge (Chambers, 1997). But at the same time, film is a technology of surveillance: it facilitates social control by delimiting what is showable and what is not. Esther Prins emphasizes in particular how much the weight of the camera's "eye" ends up by being internalized and the extent to which the subject being made visible "maintains the disciplined individual in his subjection" (Foucault, 1975/1995) p. 187, (Foucault, 1980). To understand how we treat this dilemma methodologically, it is necessary that we first take a closer look at the stakes riding on the "exposure" of our group of this category of "pluriactive farmers".

\section{The case of pluriactive sotck farmers, the filmed output and its unexpected outcomes}

Our initial intention, as researchers, was to give voice to stock farmers through the joint production of a film. There were two reasons for this approach: first, the multisensory nature of film would allow these farmers to express practices and knowledge that, because of their emotional dimensions and despite being part of the participants' identities as farmers, might not come to light in other contexts. Second, a joint filmmaking task would create the necessary medium for collaboration between researchers and farmers. We decided to focus on a category of minority stock farmers: part-time or "pluriactive" stock farmers, who raise stock (primarily cattle) part-time alongside another job. These farmers are marginalized in the agricultural community. However, they seem neither to search for specific recognition nor to avoid it, for they remain dependent on professional farmers and their institution.

Our study and the existing literature emphasize value of pluriactive farmers, however. Representing up to $20-30 \%$ of the stock raisers in areas of unintensive ranching, these farmers maintain many valuable environmental practices (Eikeland and Lie, 1999) (Kinsella et al., 2000) and employ alternative economic strategies based on principles of autonomy and cooperation (Evans and Ilbery, 1993). We chose to study this group in large part because of their unique practices. Our choice was additionally based on the following fact: the practices of these pluriactive farmers, mostly located in Gaume, a small area of 50,000 square kilometers in the southeastern tip of Belgium, differed considerably from the Belgian standard of intensive cattle farming, at least in terms of the breeds that they raised (i.e., the "Belgian Blue") (Stassart and Jamar, 2008).

The film, the final product of this project (a short version is available on the $\mathrm{Web}^{1}$ ), depicts the atypical reality of these farmers. The eight pluriactive farmers involved in the film worked with five different cattle breeds ${ }^{2}$ without our having deliberately made this choice. They were not mere "enthusiasts." On the contrary, they kept herds of from twenty to sixty head of cattle and managed the acres of pastureland and hay meadows necessary for their herds' subsistence. As a result, their relationship to the agricultural profession, and especially to full-time stock farmers, remains ambiguous. Their access to land is strongly

\footnotetext{
${ }^{1}$ The $22^{\prime}$ short version is available at http://reflexions.ulg.ac.be/cms/c_25435/ eleveur-autrement?hlText=\%C3\%A9leveur+autrement.

${ }^{2}$ Limousin(1), Blonde d'Aquitaine (2), Maine d'Anjou(1), Charolais (1), and Belgian Blue (3)
} 
caught up in the power struggles and power relationships that are common throughout the profession and among all landowners. Their small size makes them dependent on the harvesting material of professional farmers. However, full-time professional farmers envy them, for the pluriactive stock farmers benefit from a series of EU Common Agricultural Policy premiums (especially agri-environmental ones) while earning, through the employee status of their other jobs, better benefits than selfemployed professionals do.

The product of this research, a 44-min film titled "Eleveur Autrement $^{\odot \text { " }}$ (Stock Farmer otherwize), starts by describing eight previously unacquainted "pluriactives" and their diverse experiences with dual careers. Variously roofers, mailmen, blue-collar workers, office staff, school educator etc., they become farmers "after hours." The second part of the film focuses on the complexity of organizing life around two jobs, and especially on the daily need to combine two professions with very different schedules and rhythms. The third part describes the pleasure and passion that the pluractive farmers take in their work from one season to the next, and the film ends with the harvest period and cattle breeding contests, in which our part-time stock keepers come up against the country's best "professional" breeders.

Our research is unique in showing that, beyond the film's production and dissemination, ${ }^{3}$ a second unexpected dynamic emerged around the sequences that were cut in the final editing round. These cut sequences revealed hesitations and disagreements among the breeders about their own practices, especially in connection with their work and with animal welfare issues. Two dynamics were thus at work in the intersubjective relationship between the stock farmers and the researchers. The first dynamic generated, through the viewings of the film, a conventional notion of social reality based on stable representations and pre-existing categories. The second one generated around the cut sequences a very different perspective of social reality built, on the contrary, on the instability of categories and on the farmers' hesitations. This perspective interested us because it prompted the farmers to raise new questions on their own, discuss them, and eventually resolve them, This in turn forced us to revisit the theoretical question of what constitutes a pragmatic definition of a "practice."

The analysis of this research is presented in the following four sections. The first (Section 3) spells out the methodological principles of the researchers' participatory approach. The second part (Section 4) describes the film-making method with attention to two issues: how the joint production of multiple points of view took shape, and how the participant farmers engaged in the project over the course of filiming. The third part (Section 5) describes the final product, the film, while raising the question of the type of coherence that this minority group constructed and how we, as researchers, were able to interpret it. Finally, the fourth and last part (Section 6) examines, using the cut footage, what the filmmaking process can tell us about the factors that lead pluriactive stock farmers to emerge and exist as a minority group.

\section{Methodological principles of intervention research}

Over the various other terms used to describe our research - i.e., action research, deliberative research, and participatory research we prefer that of "intervention research." The intervention research

\footnotetext{
${ }^{3}$ The film was shown some ten times locally and three times nationally, while ninety copies of the DVD were sold, mainly by the breeders themselves. The trailer posted on You Tube was seen 1421 times (address: http://www.youtube.com/ watch? $\mathrm{v}=\mathrm{e} 6 \mathrm{zqB}$ 4OSTUA) (statistics on $10 / 06 / 2011$ ).
}

approach enabled us to stress our responsibility in the filmmaking project's joint construction, especially our responsibility to cope with the ethical dilemma of empowerment vs. surveillance that was mentioned above. We were seen above all as academics rather than research scientists, even though we contributed our scientific legitimacy and expertise to the project as a sociologist engaged in intervention research (Pierre) and as a filmmaker-anthropologist (Valerie). We shall therefore refer to ourselves in this text as academics when we examine our reflexive interactions with the stock farmers and as researchers when we consider only interactions among researchers.

The intervention research model (Hatchuel, 2000; David, Hatchuel et al., 2001; Hatchuel, Le Masson et al., 2002) that we adopted in our film project originates in the dialogic approaches of Maurer's action-research typology (Maurer and Githens, 2010). Maurer's typology stresses the role of professional inquiry (Schwandt, 1997; Reason, 2003) in the vein of such American pragmatists as John Dewey and Richard Rorty. According to John Dewey, social sciences in general and sociology in particular need not explain the social, turn it into theory, or divide it into categories. Rather, sociological explanations are valuable not so much as accounts of reality, but as pragmatic means to achieve real, practical goals. In the social sciences, such work can take the form of a survey aimed first and foremost at participating in the emergence of a group:

The sociological survey is supposed to be triggered by a difficulty that the investigator [or researcher] turned into an obstacle to overcome or a problem to solve. Consequently, the investigator is not an objective, neutral, empirical observer, but rather a learner who tries to determine how [things] "stick together"...who creates specific knowledge and how it can be transformed that designates not an object or an event, but a learning pathway fed by his/her own attempted modifications (Stengers, 2006).

This presentation, which was inaudible and thus carried little weight with the stock farmers, underwent a process of explicitation throughout the project. This culminated in the researchers' reformulating four principles of method: artifice, recalcitrance, no outcome guarantee, and trust.

1. The researcher recognizes the artificial, constructed link between his research set-up and the effects that it generates as a necessary link that must be made visible. Only by making this link explicit - that is, by defining the method - marks the possibility for the researcher that his/her practice is scientific in a singular manner (Thiery and Cerf, 2009). However, recognizing the use of the artifice alone is not enough.

2. The right artifices are those that can activate the recalcitrance of the people being investigated. They make what is demanded of these subjects - challenging the researchers' questions possible. So, recalcitrance is not just resistance; it is also the latter's involvement in redefining the questions to ask. The feeling of participating is what opens up the possibility of the co-evolution of learning between the researchers and social actors.

3. The researchers' (pre-)established scientific questions carry no guarantee of results. Our research projects need subjects to study, but we do not know ahead of time what our subjects are capable of doing. It is our abilities as researchers to express our purposes and interests that engages others in our work. Our role is neither to use the group nor to let ourselves be enrolled by the group (Stengers, 2009). Rather, the relationship between the two groups is rooted in reciprocity, in linking the questions and expertise of the researchers to those of the people whom 
they are studying. These relationships are embedded in each party's institutional positions and shaped by the risks that each party feels it is capable of taking (Mougenot, 2011).

4. While recognizing that results are never guaranteed, the researcher must trust that the research process, over the unpredictable course of its development, will create scientifically meaningful resources (Thiery and Cerf, 2009). This need for trust, in the pragmatic sense of the word, means that the participants must meet the following requirement: The issues put to the group cannot take the form of orders to carry out. The questions that are raised must be open questions (Stassart et al., 2008)

Dewey's social experimentation, which these four principles reflect, is characterized by a dimension of irreducible intersubjectivity. His approach renounces from the outset the researchers' positions as observers as well as the pre-existence of any social group. It recognizes instead that researchers have the obligation to trust, and participants the obligation to remain open. In our joint filmmaking project, the approach took the form of two proposals from the academics: first, to carry out a film project without an initial script, which would be built as we went along; and second, to tackle the empowerment-surveillance dilemma by building the collective of pluriactive stock farmers without defining its audience beforehand, while all the while asserting the need for a final product - the film.

Our presentation and its twofold proposal were greeted hesitantly: the "pluriactive" category was deemed oversimplified and its future uncertain. The idea of a film and the publicity that it would generate worried the farmers. It brought to light the fragility of the pluriactive stock farmers' co-existence with full-time "professional" stock farmers who share their passion for cattle breeding. The eight pluractive farmers eventually agreed to participate, giving us a tentative, "Well, we'll see what happens"-a green light to start the scouting phase. The two academics had no choice other than to accept this fragile partnership formed around a universally-shared concern: that is, what does it mean to be a "pluriactive stock farmer" in the 21st century? Let's see how this issue was handled methodologically and examine the impacts that our research approach had on the stock farmers and the researchers.

\section{Methodology of filming}

The film was shot in an iterative loop, alternating between shoots on individual farms and in group meetings. The film was shot in four steps (section 4: stage 1-3 \& section 5: stage 4), each of which was itself a further loop consisting of five phases, as follows:

\subsection{The five phases of the iterative filming/editing loop}

1. Hybrid group reflexion: eight stock farmers (8 SF) and two academics ( $2 \mathrm{U})$, facilitated by the sociologist (Us):

- Production of guidelines for the shoots.

2. Filming by the anthropologist (Ua) with an individual stock farmer (SF) who demonstrates, comments on -, and reflects on his work.

- Production "rushes".

3. Transformation of the rushes by selection and organization by (Ua).

- Production of short sequences (S).

4. Accumulation of short sequences between two meetings by (Ua).

- Production of a cut (E).
5. Screening of the cut and comments by the hybrid group.

- Production of curiosity and questioning.

Alternating between being face-to-face with the movie camera and meeting as a hybrid collective thus constituted the driving force of an interactive dynamic, with the individualized shoots out in the field triggering curiosity and questions during the group meetings. The farmers set the pace of this dynamic, for they were generally the ones who decided the right time for filming and phoned up the anthropologist to come shoot the scenes. The alternation that dynamized the iterative learning process was epistemological; the act of shooting footage that focused on farmer practices reflected an epistemology of empathy, of the ephemeral, and of the implicit - an epistemology of action - whereas the meetings, which centered on the hybrid collective, reflected a more stabilized epistemology of the explicit. This alternation set the rhythm of "...the generative dance between knowing and knowledge" (Cook and Brown, 1999). The circularity and non-linearity of this process enabled the farmers to assume control of the joint filmmaking exercise. We shall now describe the three other methodological dimensions of our intervention research by examining the three stages of filiming.

\subsection{Stage 1: Scouting and engagement}

The purpose of this first loop was to show that the film project was indeed technically and thematically feasible. In terms of methodology, the idea in these first moments of filming was to let the non-verbal guide the verbal (MacDougall, 1997), to distance oneself from the interview technique in order to encourage exploration. The farmers demonstrated and commented. By varying her role and position, the camerawoman/anthropologist (Ua) helped fuel the farmers' exploration: (Ua) would first roll the film and let things happen without interfering; then, she might suggest that the farmer switch from demonstration to commentatary; and, finally, she would let things freely occur outside the camera's field. The golden rule was "non-control."

At the end of this first round of shooting, the stock farmers were happy with the first cut (E1) of nineteen sequences (S1-S19) (see Table 1, below). However, the academics had mixed feelings. They felt trapped by the images, which they considered to be ordinary, and they feared that the cut would end as banal as it had begun. However, a surprisingly graphic shot - the sequence of the unexpected birth of a stillborn lamb - sparked sudden controversy.

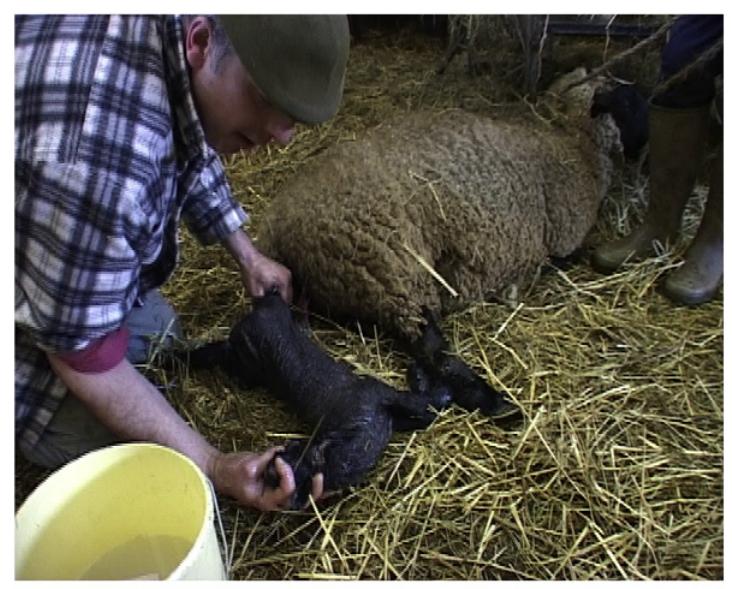

Illustration 1: stillborn lamb sequence (S19) 
Table 1

Individual scoring of the 34 sequences available for the final editing - Stage 4 (E4).

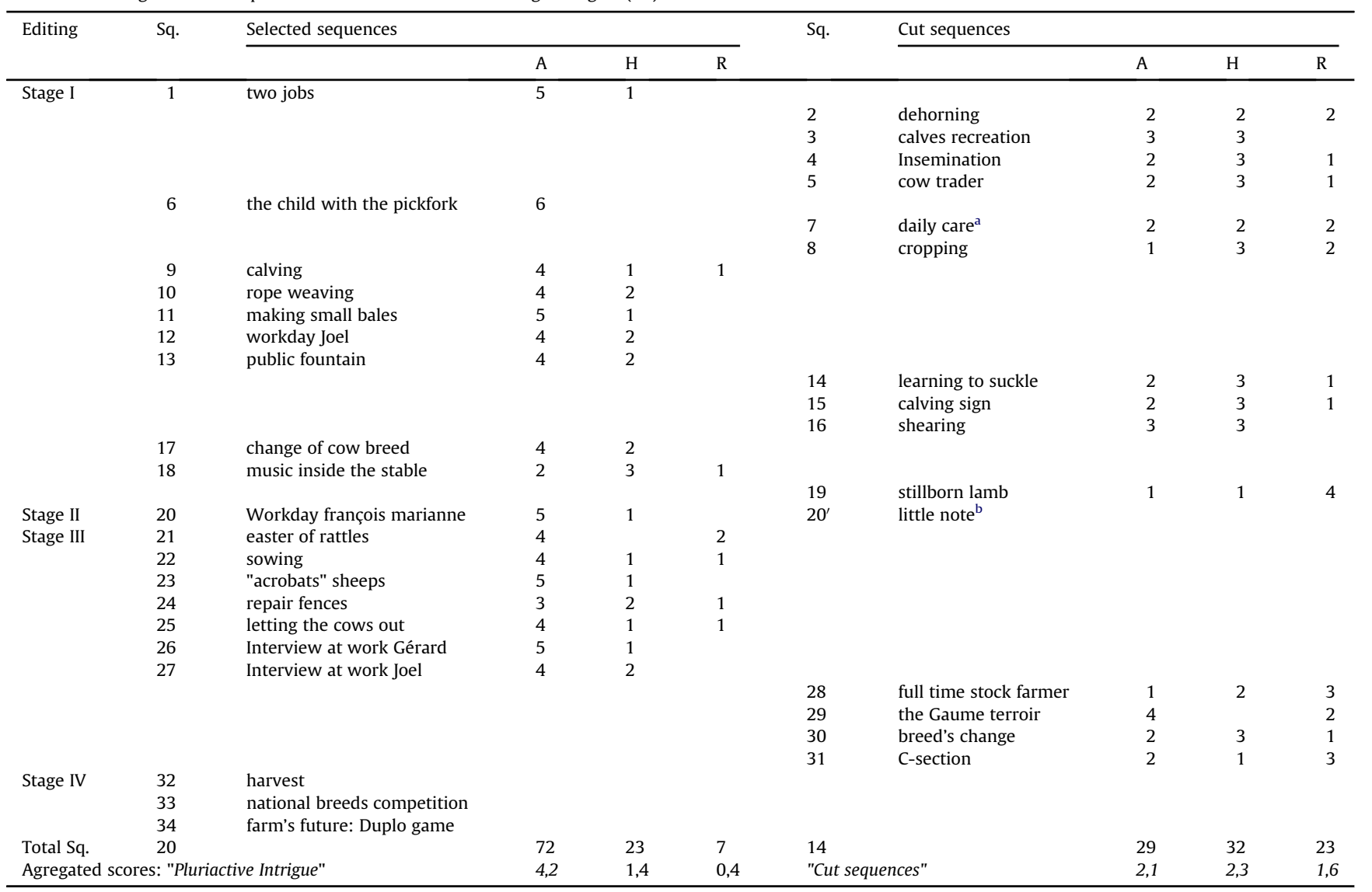

a changed sequences.

b footage cut from S20.

The farmers wanted to drop this sequence. They were afraid the film's implicit audience - that is, professional stock farmers would accuse them of being amateurs, The discussion raised the issue of "audience" and forced the farmers to confront their intial decision to maximize transparency. For the academics, on the contrary, this sequence appeared especially interesting and extremely well-suited to their public, the scientific community. The sequence remained in limbo, but by engaging the members of the two groups the controversy helped build a basic level of attachment and understanding within the group. Still, this first very generic cut said nothing about what distinguishes part-time pluriactive farmers from their full-time professional colleagues. The group thus decided to refocus the second filming loop on their typical daily lives, on the cycle between off-the-farm jobs (as postman, blue-collar worker, etc.) and on-farm work.

\subsection{Stage 2: Singularizing the "we"}

Methodologically, the anthropologist equipped or empowered the filming of the farmers' daily lives by distancing herself from the production process. She employed two strategies to put the production in the hands of the farmers. First, she had the farmers do their own self-staging (or "auto-mise en scène"), which transformed them from subjects into actors. Second, she had the same participants and their families review and comment on the sequences.

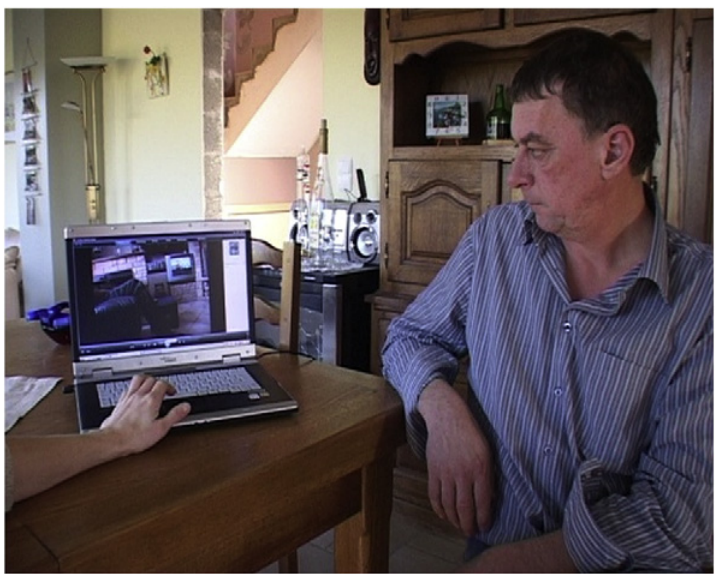

Illustration 2: Reviewing and commenting on a sequence

This strategy of distancing impelled the farmers to engage the material in surprising ways. Having two spaces all to themselves in which to circulate and review video sequences liberated them from the "need to please" the researchers. With their increased freedom, however, they chose to increasingly disregard the moral 
issue of transparency. When certain farmers protested, “Don't film that!," they were responding to the looming shadow of naïve lay audiences unfamiliar with the harsh realities of stock farming. These objections occurred most frequently with images showing the farmers' relationship to the animals: hitting the livestock, getting upset with them, and revealing glimpses of the grittier side of farming.

When their defensive reflexes turned, instead, to "You may film it, but you mustn't show it!," two audiences became involved: an "us" and a "them." An interior space emerged. A "we," a hybrid collective compsed of stock farmers and academics, took shape (Callon et al., 2011). The "others" inhabited an outer space, a multiform and unclearly-defined audience made up of local residents, non-farming citizens, and professional stock farmers. The "we" gave rise to important but unshowable sequences. The "we" worked to transform certain sequences so they might be able to cross the border into the exterior, public arena.

This "us"|"them" distinction lies at the foundation of a second dynamic: that which emerged around the cut sequences. We, as researchers, paid close attention to how this dynamic evolved. It equipped us and taught us how incorporate the notion of hesitation into the pragmatist definition of "practices". (We shall come back to this in Section 7.) From an empirical point of view, the cut (E2) that came out of this second filming loop surprised us as academics. It exposed the incredible organizational demands of the pluriactive farmers' double work life. This realization thus brought us to the focus of the third filming loop: what keeps these overworked, "slightly crazy" part-time farmers going?

\subsection{Stage 3: The springs of the pluriactivity}

Going from "how" to "why" is a difficult, even violent, operation. It is the researcher's most important question. It delves into the deepest, most intimate reaches of identity. "It's like going to confession" one farmer admitted. In terms of methodology, the challenge is dealing with this silence, this void that enables one to perceive what has not yet risen to the conscious level (Vermersh, 1999). So, Valerie responded by creating a third form of distance in the shoots, taking the filming and interviewing to the farmers' off-farm work places. This had two paradoxical effects: on one hand, it brought to light the farmers' true passions for cattle breeding while, at the same time, it led many of them to disengage from the film project. The material filmed during two off-farm interviews (S21-S31) revealed the passion these pluriactive farmers feel for their on-farm work, feelings that go far beyond the common refrain of "It's in our blood." However, the collective commentary about this third cut (E3 of S21-S31) made people nervous and trepidatious. The stock farmers could not decide whether to proceed with the project or back out entirely. They felt caught between the risk "of having problems afterwards" with the professional farmers and the risk of proving themselves mere "hobby farmers" by backing out. In this case, showing one's passion clearly exposed one to risk. Some of the farmers proposed to disengage themselves from the film project, claiming, "We made this film just to please you academics!" For the academics, the joint filmmaking process had reached a turning point. The project began to falter under the weight of having to produce for a real audience. However, the hesitations were to be overcome by the emergence of a new player in the hybrid collective: the farmers' wives.

The farmers' wives were practically invisible in the first phase of the filming. Their presence was limited to that of the hostess who discreetly opened her home to the farmers and academics as they screened cuts and decided on their future courses of action.
In the second loop, however, the women became more involved in the project by participating in the self-staging sessions and footage reviews. Finally, in the third loop, several of them took an active part in the screening and orientation meeting. In the face of the men's indecisiveness, the wives voiced their support for an intermediate step originally proposed by the academics: to preview the film on a test audience of relatives and close friends.

Presenting the true spirit of pluractive farming and the passion of the farmers thus did not come without risks. The process became negotiable through two operations: enlarging the "we" of the hybrid collective to include the wives, who themselves had a large stake in the pluriactive projects; and testing the film on the "intermediate public" of the families' close friends and relatives. Before describing in detail the fourth and last filming stage, let us return to the elements of method and their effects on the actors' engagement in and commitment to the project.

\subsection{Reviewing the method}

Let us recall that our first hypothesis was that the presentation of a minority group would require that the researchers be closely and socially involved in the project. Their engagement would be intersubjective. The project forced us to grapple with the ethical dilemma of empowerment vs. surveillance. Four methodological components - that is, the iterative "looping" plan for filming, the alternation between the epistemology of action and epistemology of reflection, the variations in the position and role of the camera, and the strategies for creating reflexive distance - "empowered" or "equipped" the farmers, that is to say, gave them a ownership of the filmmaking process. Implemented together, the four components created a "we" within the hybrid group of stock farmers and academics, showing that "...learning is more about providing space and time for new meaning to emerge" (Snowden, 2002). Although this mode of empowerment could not eliminate aspects of surveillance, the surveillance became shared. With no pre-established script to constrain the work, participants and researchers constructed and interpreted the mechanisms of surveillance collaboratively, dynamically, and spontaneously. Further, having no pre-set audience made the risk of presenting oneself as a pluriactive farmer more easily negotiable and encouraged the construction of a more complex group identity (the "we"). Thanks to the absence of a pre-established script and audience, the project was able to achieve the first and second principles of "good artifice" that is, it became a device to engage researchers and stock farmers in an intersubjective manner. The next section of this paper will analyze what the reflexive audiovisual method generated as a final product - namely, the film.

\section{The film and the plot $\&$ the fourth stage}

The final cut requires building a script. This script will organize the plot, which in turn will present an interpretation of the job and the life of the "pluriactive stock farmer." The film's story is actually composed of a double-layered narrative that emerged from two different types of filming and sequence (see Table 1 ). The first layer, the background, is composed of eight sequences captured in-field, as opportunities for interesting images and encounters arise. These sequences tell a sort of "metastory" describing the permanence of the small-farming community, the immutable order of the countryside of the countryside (S22, S6, $\mathrm{S} 13, \mathrm{~S} 21$ ), and resistance to modernity and its technical advances and excesses (S10). 

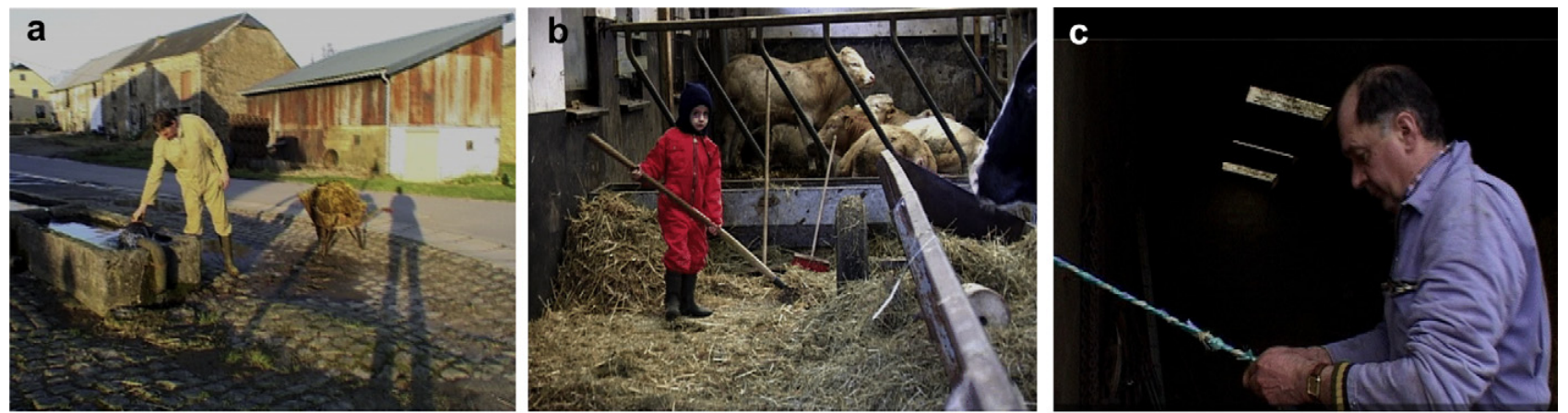

Illustration 3. Meta-story of constancy: the fountain (S13), child with a pitchfork (S6), braiding baling string (S10)

The second layer, the foreground, weaves the film's plot from twelve sequences planned and commissioned by the hybrid farmers-researchers collective. It is here that the keys to the pluriactive life come to light: the pleasure of alternating between two jobs, the transformation linked to the changing seasons (S23, S25, S32), and the autonomy made possible by production limits (S11, S26, S27). The film's ending is heroic; in the national cattle shows, two of our eight pluriactive farmers snatch first prize out from under the noses of the country's "professional" breeders (S33). The "pluriactive" plot thus unfolds in three parts: (1) We are nice country folk and likeable farmers but (2) we are also professionals, as proven by our victories at the non-Belgian Blue cattle breeding competitions. (3) However, we have not fallen into the productivist trap; we can show ourselves taking a nap without sacrificing our professionalism.

\section{Sequences connected to "practices"}

A certain number of the sequences cut from the final edit that we have just described were given particular attention, for they touched on something that the stock farmers did not want to subject to an outside gaze-namely, "practices" that defined their group identity.

To understand this process, we have to go back to the final cut (E4), which was the culmination of the fourth loop. To build the script of the plot as described above, the academics proposed that the stock farmers rate the thirty-four sequences that had been produced (Mathieu, 2007). The sequences were first rated individually: each farmer scored the sequences at home using a scale of three values: + (accept), +- (hesitate), and - (reject). Next, these individual scores were aggregated to produce a collective score by a

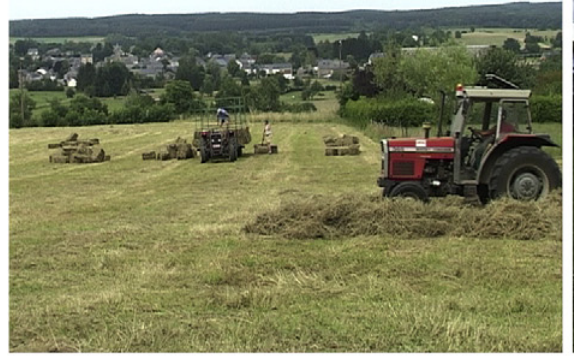

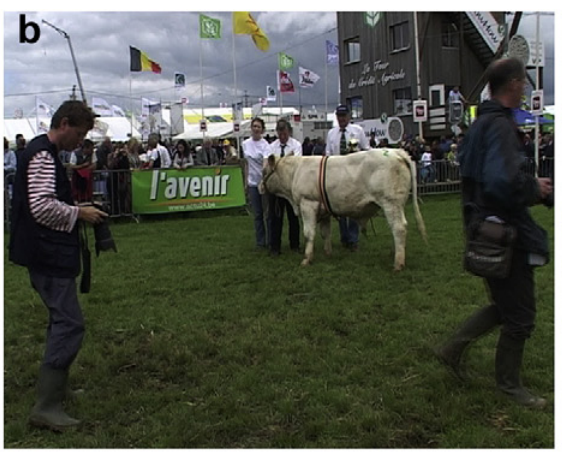

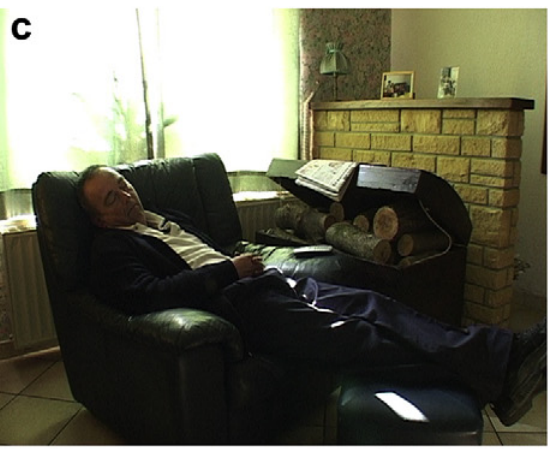

Illustration 4: The plot: harvesting (S11), the show (S33), the nap (S20)

The path of the script creates a sort of teleological arrow, one aimed at painting an image that elevates the status of the pluriactive farmers while remaining acceptable to public audiences. This construction offers a unitary perspective in which we witness the stock farmers face numerous challenges in defining their identity as "pluriactives" (having two jobs, co-existing with professionals, etc.) as they progress toward a happy ending. However, the beautiful unitary story masks some polyphonic strands (Gare, 2001). Behind the scenes, in the space of the collective, hybrid "we," the cut sequences circulate. These sequences shake up the experiment and reveal another dynamic upon which our second hypothesis - that of the creation of the social - rests. sequence (these are shown in the table below). The hybrid collective then made its final choices based on these collective scores. In the end, twenty sequences were chosen for the film (E4) and fourteen were rejected. The latter are the cut sequences.

So, the nap sequence, for example, got an aggregate score of $5-1-0$-that is, five stock farmers approved of it, one hesitated, and no one rejected it. ${ }^{4}$ The mean score of the sequences kept in

\footnotetext{
${ }^{4}$ The combined score was based on six rather than eight individual scores because one farmer did not answer and another one was willing to show everything. The scores concerned the 31 sequences of the first three loops and were determined during the filming in the fourth and last loop.
} 
the film was $4.2-1.4-0.4$, whereas that of the cut sequences was 2.1-2.3-1.6. The cut sequences thus oscillated between Acceptance (A), Hesitation (H), and Rejection (R). A finer analysis reveals two types of cut sequence: hesitations and bifurcations.

\subsection{Hesitations}

In developing her notion of divergence, Stengers (2006) indicates that a group of practitioners is a set of people who share ways of doing things that are not interchangeable-that is to say, ways that define them as a group but also create divergence among them. Practice defined in this way is not defined sociologically by standards, conventions, habits, and traditionsin other words, by all that makes it stable or normal. On the contrary, it is defined by what makes it unstable and questionable, by what makes the practitioners hesitate. By looking at the sequences cut from the final film, we can see precisely how some of the stock farmers diverged when it came to their practices.

This was the case for the practice of "dehorning" (S2). The practice is commonly performed to ensure safe handling of the stock, but some of our pluriactive farmers refused to do it because of the bloodiness of the operation and the resulting loss of herd/flock hierarchy regulation (one of the horns' functions). Likewise, while insemination (S4) from outside semen donors opens the door to better genetic performance, some farmers prefer natural mating, which produces more robust calves. The cut sequences thus created divergence among the group's livestock farmers. At first glance, these divergences might be attributed to the differences among the five cattle breeds involved. However, it was one sole breed - the Belgian Blue that caused the most hesitation. The revision done on the "suckling calf" sequence (S14) helps illustrate the case. This scene followed the efforts of a farmer's wife to teach a Belgian Blue calf how to suckle despite its macroglossia. ${ }^{5}$ The farmer, who was not present for the shooting of the sequence, was deeply torn when he viewed and commented on it afterward. He was full of admiration for his wife's calm, creative and determined work, which he discovered for the first time in this footage. He watched her try to get the calf to suckle, stimulate the teat by milking the cow, give the calf a taste of the milk in a bottle, direct the stream of milk from the udder toward the calf's muzzle, put the calf's muzzle on the udder, etc.-all very prudently, taking care to protect herself from being kicked by the cow and butted by the calf. At the same time, he was embarrassed by the sequence's length, the sight of the hypertrophied tongue and Cesarean scar, and the repeated attempts to get the calf to suckle. What should one think about this need to compensate for deficiencies in natural functions? What should one say about the direction and limits of selection in the Belgian Blue, which leads to frequent anomalies? The farmers as a group similarly wavered between the farmer's admiration for his wife's work and the potential reflection of the Belgian Blue's flaws on the collective; as a result, the sequence's aggregate score was $2-3-1$. In the end, the sequence was not actually dropped, but instead lightened by the commentary and shortened.

\footnotetext{
${ }^{5}$ Macroglossia: Hypertrophy occurs in the hypoglossus just as in the other muscles. The adverse consequences of the swollen tongue usually diminish or disappear as the animals grow older. Yet a swollen tongue causes suckling difficulties for the calf, which may even lead to death, and in some cases the mouth may be deformed Lips, et al. (2001). Ethical Objections to Cesareans: Implication on the future of the Belgian White Blue. EurSafe 2001, Food Safety, Food Quality, Food Ethics, Florence, EURSAFE. 1.
}

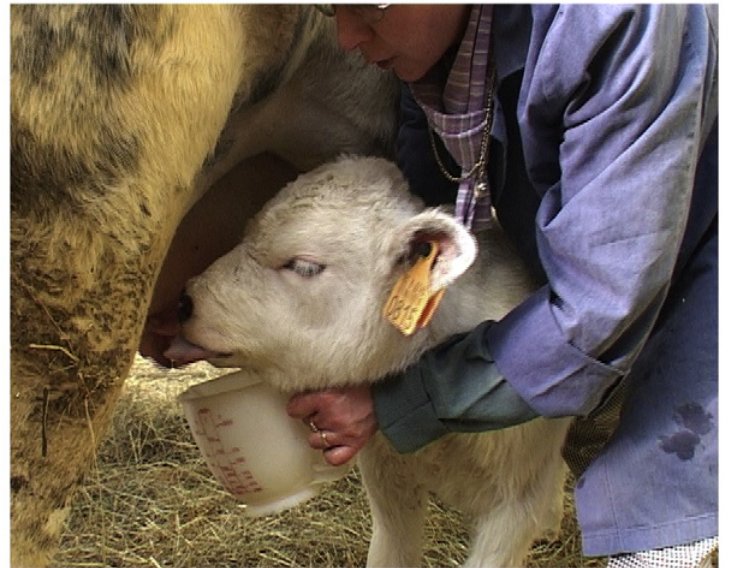

Illustration 5. Hesitation: the suckling calf, "beautiful work" or the genetically flawed Belgian Blue? (S14)

This process of making their practices visible forced the farmers to confront larger public concerns. The pluriactives felt that they did not have an empathetic audience in the public, and so had a hard time deciding how to present and gain recognition for their (divergent) practices. We, as researchers, were transformed by watching and working on this sequence. In the course of our ten years of research, the Belgian Blue successively became the archetype of productivism and thus a perfect target for its opposition (Stassart and Whatmore, 2003). Then, as time passed and the observed-observer relationship became more distant, it evolved into a beautiful subject of sociotechnical inquiry, fascinating for the irreversibility of its trajectory (Stassart and Jamar, 2008). The intensity of the farmer's hesitation about his wife's work and then the hesitation of the entire collective brought us to the heart of the Belgian Blue breeders' passion. Through the scene, we learned how to recognize and understand these breeders' very strong feelings for their work. All of a sudden it was no longer possible to set oneself up as a censor of something that the rare non-professionals who are aware of this characteristic of the Belgian Blue commonly call a "technological monstrosity."

The description of the work in this sequence shows how the researchers equip the stock farmers, through the joint film-making process, to deal with their questions and, in so doing, get a collective grip on the issue, discuss their hesitations, and perhaps become capable of sharing them in a relatable way. This experience also sheds light on the distinction between belonging and identity.

For Stengers and Deleuze (Stengers, 2006: 240), an "idiot" is someone who resists the pressure of consensus, preoccupied with something more important or exceptional-in this case, the calf and its macroglossia. What matters to these pluriactive stock farmers and causes them to diverge does not box them in. It owes instead to a spirit of speculation about what is possible. They are practitioners. For Deleuze, the idiot slows down where others, mobilized by a consensual urgency, rush forward. That is why these practices (teaching the calf to suckle, dehorning, and artificial insemination, but also the "shearing" sequence (S16) before the return to the barn or the "recreation" sequence (S11)), demand as strict a separation as possible between their private realm of hesitation and the external public realm. They do not want to expose themselves to a public's "artificializing" interpretation (of insemination or dehorning). However, among themselves, hesitation is allowed, because a "we" took shape during the joint filmmaking.

\subsection{Skids and bifurcations}

Deleuze speaks of lines of escape, or nomad lines. The main characteristics of these lines are bifurcations, uncontrolled skids, 
endings that are impossible to foresee at the outset. (Deleuze and Parnet, 1996). We identified a series of five cut sequences, the mean score of which (1.7-1.3-3) showed that they had been clearly rejected, compared with a mean score of 2.4-2.8-0.8 for the sequences over which there was hesitation. These "suspended" sequences were rejected by the farmers because they represented nomad stories that might take them where they did not want to go-create a fork in the road, or a skid. For example, the sequence called "the little note" (S34) showed a farmer's wife reading a small piece of paper on which her husband had jotted down instructions for what had to be done while he was away. The image of this piece of paper brought forth the issue of the legitimacy of these part-time farmers, who were forced to rely on the help of "outsiders" because of their own limited availability. Could it still be considered stock farming when one was so dependent on outsiders? This question raises the issue of one's relationship with work, which we shall not cover here. Likewise, the "daily care" sequence (S7), was dropped because a cow's hind end that was clearly "soiled" with its own excrement could be seen in the background, and this might "cause ripples."

The main mechanism of these narrative sequences is the "password" (Schapp, 1992): a minor element in the story (which at first existed only in the background or foreground) suddenly becomes a core element, shifting the story such that the moment preceding this change is immediately relegated to, at best, the status of "pre-story." At this point, the farmers' vulnerability no longer stems from divergence, but from the absence of a receptive audience and the risk of bifurcation or skidding. So, in the case of the daily care sequence, the password "soiled hindquarters" effectively opens the door to a condemnation of dubious hygiene presumedly linked to the close quarters in which peasants and livestock live. This stems from common confusion about animal welfare, which is perpetuated by the remoteness and ultrahygienicity of modern animal husbandry (Despret and Porcher, 2007).

Another sequence, that the sequence of the Ccesarean section (S31) highlighted the issue of the human-animal relationship even more. It showed the farmers expressing their reservations over a practice of which the public is hardly aware-namely, systematic calving by C-section. The footage showed the details of the operation: the cow's flank was carefully disinfected and shaved, then opened with a single, precise stroke of the scalpel. Blood spurted out, very quickly followed by the head of a calf that seemed to come out of nowhere. The live filming of the blade's movements, which gave life while just grazing death, and the cold, mechanical opening of the womb raised a fundamental question: to what extent should life be instrumentalized? To the point of using C-sections like zippers to deliver the products of the Belgian Blue's genetic performance? Here, the turn-off is very close to an uncontrolled skid, if not one already.

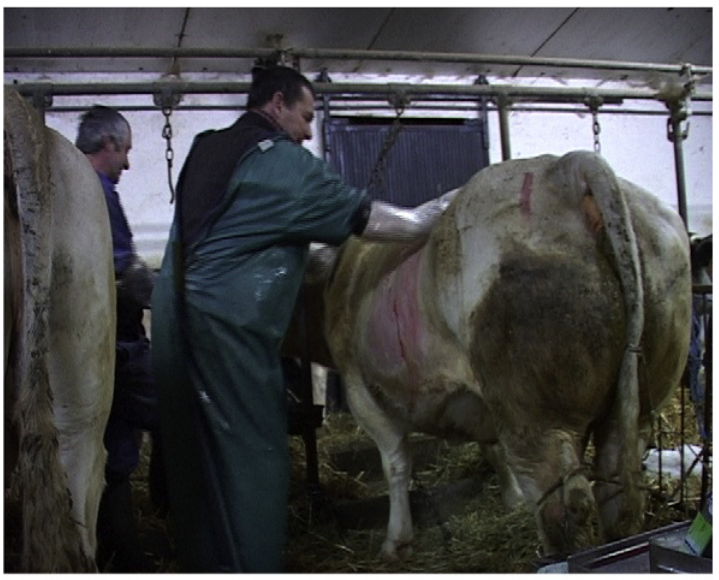

Illustration 6. bifurcation: C-section (S31)
This sequence is embedded within a context where the relationship with the animal is eliminated either through transparency "from stable to table" in the meat industry and animal welfare societies' actions or by idealizing the raising of domesticated animals and barnyard fowl as members of the household. How, then, can one convey reality when the public is caught between these two myths? How can one diverge without exposing oneself to the simplistic reproach of artificialization? And yet, this hybrid group did diverge over these practices: some spoke of C-sections, others of natural calving (which nevertheless entailed pulling the calf out of the womb in the stable), and still others of calving naturally out on the range. Although these diverse breeders diverged and hesitated in watching the Csection and suckling calf sequences, they could not debate these issues. Through the filmmaking experience the farmers became anchored in practice and physical contact with their animals. They could thus become sensitive to their experience, and the cut sequences provided a means to talk about it among themselves.

\section{Epilogue}

As researchers we built our intersubjectivity within the hybrid collective of stock farmers and academics by repeatedly asking who owned the film. This question is usually approached from the standpoints of property (copyright) and broadcasting rights. In our case, the issue that got everyone engaged was ownership of the framing and nuances of the film project. The question of ownership became even more pronounced in regards to the cut sequences. "Burn them!" one farmer burst out. The anthropologist, intrigued, countered, "Why burn them?" The response came from the same farmer, and was included unchanged in the charter on the film's use: "The cut sequences are like a body donated to science. We give them to you. Use discretion with them according to this principle." The practitioners stood fast in the face of public urgency, but hesitated with those who tried to share their passion. As they had told the anthropologist, "You are one of us!"

\section{Final comments}

Without an initial guarantee of results (Principles 3 and 4 of the method), the empirical risk that the authors shouldered in making this film without a pre-established script rested upon their trust in the process. In three sections we have described how intervention research produced, through the expectations of the plot, the unexpectedness of the cut sequences. However, to what type of scientific risk did they ultimately expose themselves? The farmers' presentation of themselves and their work in the film is open to possible contestation: this presentation might be deliberately truncated; it might hide important issues such as that of the Csection. Answering this question requires that the endeavor be understood as a practice of emergence as well as an obligation to define what has emerged.

We argue that our purpose was not to make a film portraying the farmers and the pluriactive or two-job plot, but rather to see what would happen as a result of the filmmaking itself, i.e., the secondary dynamics around the cut sequences. The risks did not present a major concern or controversy, but rather the possibility of creating an inquiry around the pluriactive farmers' practices that were assumed to be alternative or minority practices (Stengers, 1994). Our research practice, defined by the task of finding the "right artifice", was aimed at giving the actors a "handle" on the proceedings so as to turn them gradually and partially into research partners. 
This notion of a "handle", or latching onto a process, is too weak, however, for it is vulnerable to the empowerment-surveillance dilemma and thus the risk of manipulation. The proposed solution was counter-effectuation \{Deleuze, 1990 \#1992\}. In the course of the research, shifting from the first to the second dynamic we focused on situations in which constraints could be perceptible, because this made the actors hesitate in the empirical realm of concrete experience. Counter-effectuation then consists of heading toward the abstract constraint, toward that which makes one hesitate (Thiery and Cerf, 2009:31).

This counter-effectuation was partial. The cut sequences tell us that the farmers stood fast against public urgency. They neither wanted nor were able to decide on certain practices. In particular, they resisted the threat of being reduced by the artificialization of stock farming practices. We did not have the material means to learn how the voicing and sharing of their hesitations may have changed their sense of what was important, but we can wonder whether making these divergences (over the calf's macroglossia, dehorning, insemination, etc.) explicit, by subjecting them to debate (in terms of practices that were not interchangeable), would cause a Deweysian public to emerge. Only in these terms can one speak of the emergence of minority practices.

Within the framework of these limits, we can thus draw the following teachings lessons from our experience: the film artifice that got people involved hinged on a paradox, for there was no preconstituted collective, but rather an emerging collective made of heterogeneous elements, i.e., eight livestock farmers, their wives and children, and two researchers. We termed this group a hybrid collective. What is more, it took shape along with its audience. The learning process is incomplete; it may continue with the film's dissemination and exposure to debate. Indeed, the several screenings held to date show that its audience is gradually shifting from an audience in the conventional sense of the word to a public in Dewey's sense of the word, i.e., a concerned public.

The construction of this potential collective was also guided by the idea of co-existence with the expert majority-in this case, the champions of the Belgian Blue model. Co-existence is a necessary condition for their existence, for it protects them from the risk of exposure and the threat losing group belonging. However, this refers paradoxically back to the following question: if the possible emergence of the collective of pluriactive farmers allows minority practices to emerge, do these minority practices occur exclusively in this group or are they also present but mute in the work of full-time professional farmers? We hypothesize that only the realm of expression created by the reflexive audiovisual methodology is unique to this group, whereas these minority practices are indeed present, albeit in the background, in the dominant model of the Belgian Blue. This hypothesis is crucial, for it opens the door, through similar schemes, to questions and thus further developments around issues of stock farming's unsustainability, such as its artificialization. It creates new leeway to explore in helping these livestock farming models transition toward greater sustainability.

Finally, from a methodological point of view, using a reflexive film tool enabled us to document exactly what the group had in common and where they diverged. Drawing on the language of Stengers and Dewey, we can say that this method was created and made possible - by the researchers' expertise: it relied on there being a pre-defined problematic and as well as an instrument to handle it (i.e. the film project). However, what really propelled the investigation was not the researchers' initiative but the cooperative process of modification made possible by the dynamic exchange between camera, researchers, partner farmers and audience.

\section{Appendix. Supplementary data}

Supplementary data associated with this article can be found in the online version, at doi:10.1016/j.jrurstud.2011.07.007.

\section{References}

Banks, M., 1998. Visual anthropology: image, object and interpretation. In: Prosser, J. (Ed.), Image-based Research, a Sourcebook for Qualitative Research. Falmer Press, London, pp. 9-19.

Barndt, D., 2001. Making, naming, and connecting - reclaiming lost arts: the pedagogical possibilities of photo story production. In: Campbell, P., Burnaby, B. (Eds.), Participatory Practices in Adult Education. Lawrence Erlbaum, Mahwah, NJ, pp. 31-54.

Callon, M., Lascoumes, P., et al., 2011. Acting in an Uncertain World: An Essay on Technical Democracy. MIT Press, Boston.

Catalani, C., Minkler, M., 2010. Photovoice: a review of the literature in health and public health. Health Education \& Behavior 37 (3), 424-451.

Chambers, 1989. Farmers First8. Intermediary Technology Publication, London.

Chambers, R., 1997. Whose Reality Counts? Putting the First Last. London, Intermediate Technology Publications, London.

Cook, S.D.N., Brown, J.S., 1999. Bridging Epistemologies: the generative dance between organizational knowledge and organizational knowing. Organization Science 10 (4), 381-400.

David, A., Hatchuel, A., et al., 2001. Les nouvelles fondations des sciences de gestion. Vuibert/Fnege, Paris.

Deleuze, G., 1990. The Logic of Sense. Athlone, London.

Deleuze, G., Parnet, C., 1996. Dialogue. Flamarion, Paris.

Despret, V., Porcher, J., 2007. Etre Bete. Acte Sud.

Eikeland, S., Lie, I., 1999. Pluriactivity in rural Norway. Journal of Rural Studies 15, 405-415.

Evans, N.J., Ilbery, B.W., 1993. The pluriactivity, part-time farming, and farm diversification debate. Environment and Planning A 25, 945-959.

Foucault, M., 1975/1995. Discipline and Punish: The Birth of the Prison. Vintage Books, New York

Foucault, M., 1980. Power/knowledge: Selected Interviews and Other Writings, 1972-1977. Pantheon Books, New York

Freire, P., 1973. Pedagogy of the Oppressed. The Seabury Press, New York.

Gare, A., 2001. Narratives And The Ethics And Politics of Environmentalism: The Transformative Powers of Stories. Theory \& Science captured 3 september 2010: http://theoryandscience.icaap.org/content/vol002.001/04gare.html.

Greenwood, D., Levin, M., 1998. An Introduction to Action Research: Social Research for Social Change. Thousand Oaks, CA: SAGE.

Hajer, M., 1995. Politics on the move: the democratic control of the design of sustainable technologies. Knowledge, Technology \& Policy 8 (4), 26-39.

Hatchuel, A., 2000. Research, Intervention and the Production of knowledge. In: Cerf, M., Gibbon, D., Hubert, B., et al. (Eds.), Cow up a Tree: Knowing and Learning for Change in Agriculture. Coll. Science Update, Inra Edition, Paris, pp. 55-68.

Hatchuel, A., Le Masson, P., Kinsella, J., Wilson, S., de Jong, F., Renting, H., 2002. From knowledge management to design-oriented organisations. International Social Science Journal 171, 25-37.

Kinsella, Jim, Wilson, Susan, de Jong, Floor, Renting, Henk, 2000. "Pluriactivity as a Livelihood strategy in Irish farm households and its role in rural development. Sociologia Ruralis 40 (4), 481-496.

Kemp, R., Parto, S., et al., 2005. Governance for sustaina-ble development: moving from theory to practice. Journal of Sustainable Development $8(1-2), 13-30$.

Lips, D., De Tavernier, J. Decuypere, E., Van Outryve, J. 2001. Ethical Objections to Cesareans: Implication on the future of the Belgian White Blue. In: Ethical Objections to Cesareans: Implication on the future of the Belgian White Blue, EurSafe 2001, Food Safety, Food Quality, Food Ethics. EURSAFE, Florence, pp. 291-294.

MacDougall, 1997. In: Banks, M., Morphy, H. (Eds.), The Visual in Anthropology Rethinking Visual Anthropology. Yale University Press, London.

Maguire, P. (1987) Maguire, P., 1987. Doing Participatory Research: a Feminist Approach. Center for International Education, School of Education, University of Massachusetts, Amherst, MA.

Mathieu, V., 2007. In: Vers le montage final: questionnaire, vol. 8. Liège University, Arlon Campus, SEED, Arlon.

Maurer, M., Githens, R.P., 2010. Toward a reframing of action research for human resource and organization development. Action Research 8 (3), 267-292.

Mcintyre, A., 2003. Through the eyes of women: photovoice and participatory research as tools for reimagining place. Gender, place \& culture. A Journal of Feminist Geography 10 (1), 47-66.

Mougenot, C., 2011. Raconter le paysage de la recherche. QUAE, Paris.

Newman, P., Kenworthy, J., 1999. Sustainability and Cities. Overcoming Automobile Dependence. Is-land Press, Washington, DC (Washington, DC, Island Press).

Pini, M., 2001. Video Diaries: Questions of Authenticity and Fabrication. Screening the Past Retrieved march 2, 2011, from. http://www.latrobe.edu.au/ screeningthepast/current/cc1201.html.

Pink, S., 2001. More visualising, more methodologies: on video, reflexivity and qualitative research. The Sociological Review 49 (4), 586-599.

Prins, E., 2010. Participatory photography: a tool for empowerment or surveillance? Action Research 8 (4), 426-443.

Reason, P., 2003. Pragmatist philosophy and action research. Action Research 1 (1), 103-123. 
Rouch, 2003. Camera and Man. In: Hocking, P. (Ed.), Principles of Visual Anthropology. Mouton de Gruyter, Berlin, pp. 79-98.

Ruby, J.A.Y., 1980. Exposing yourself: reflexivity, anthropology, and film. Semiotica 30 (1-2), 153-180

Ruby, J.A.Y., 2000. Picturing Culture:Exploration of Film and Anthropology. University Chicago Press, Chicago.

Schapp, W., 1992. Empêtrés dans des histoires, L'être de l'homme et de la chose. Cerf, Paris

Schwandt, T.A., 1997. The landscape of values in evaluation: charted terrain and unexplored territory. New Directions for Evaluation 1997 (76), 25-39.

Shields, V.R., Dervin, B., 1993. Sense-making in Feminist Social Science Research: a call to enlarge the methodological options of feminist studies. Women's Studies International Forum 16 (1), 65-81.

Smith, L., Bratini, L., et al., 2010. Between idealism and reality: meeting the sagepub. challenges of participatory action research. Action Research 8 (4), 407-425.

Snowden, D., 2002. Complex acts of knowing: paradox and descriptive selfawareness. Journal of Knowledge Management 6, 100-111.

Stassart, P.M., Jamar, D., 2008. Steak up to the horns! The conventionalization of organic stock farming: knowledge lock-in in the agrifood chain. GeoJournal 73 (1), 31-44.
Stassart, P., Mormont, M., Jamar, D., 2008. Recherche Intervention pour la Transition vers le Développement Durable. Economie Rurale 306, 8-22.

Stassart, P.M., Whatmore, S.J., 2003. Metabolising risk: food scares and the un/remaking of Belgian beef. Environment and Planning A 35, 449-462.

Stengers, I., 1994. Une autre science. Sextant 2, 145-156.

Stengers, I., 1997. Power and Invention. University of Minnesota Press, Mineapolis. Stengers, I., 2006. La vierge et le neutrino, des scientifiques dans la tourmente. Les empêcheurs de penser en rond, Paris.

Stengers, I., 2009. Au temps des catastrophes, résister à la barbarie qui vient. La Découverte, Paris.

Thiery, O., Cerf, M., 2009. Penser la recherche participative comme une pratique une proposition de diagnostique. In: Béguin, P., Cerf, M. (Eds.), Dynamique des Savoirs, dynamiques des changements. Octarès, Toulouse, pp. 29-50.

Vermersh, P., 1999. Approche du singulier. Expliciter 30, 1-7.

Wang, C.C., 1999. Photovoice: a participatory action research strategy Applied to Women's Health. Journal of Women's Health 8 (2), 185-192.

Wang, C.C., Redwood-Jones, Y.A., 2001. Photovoice ethics: perspectives from flint photovoice. Health Education \& Behavior 28 (5), 560-572.

Williams, J., Lykes, M.B., 2003. Bridging theory and practice: using reflexive cycles in feminist participatory action research. Feminism \& Psychology 13 (3), 287-294. 